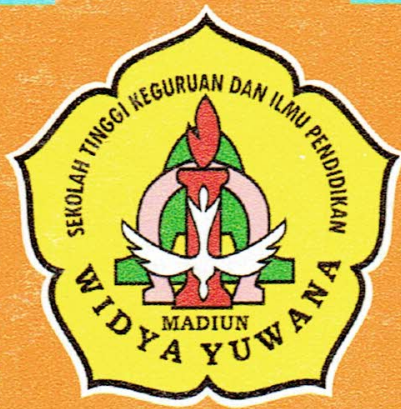

Vol. 9, Tahun ke-5, April 2013

ISSN; 2085.0743

PASTORAL PENGATURAN KEHAMILAN SETURUT AJARAN MORAL GEREJA KATOLIK

Antonius Virdei Eresto Gaudiawan, M.Hum.

ARAH DASAR PENDIDIKAN KITA

Prof. Dr. John Tondowidjojo, CM

PENDIDIKAN KARAKTER DALAM PEMBELAJARAN AGAMA KATOLIK DI SMA SANTO BONAVENTURA MADIUN

Murlani

PENDIDIKAN KRISTIANI MELALUI PENGALAMAN BERKOMUNITAS BAGI ANAK-ANAK Albert I Ketut Deni W.

\title{
MENDIDIK MURID MENJADI PENDIDIK IMAN
}

Agustinus Supriyadi

KOMUNITAS BASIS GEREJANI

Ola Rongan Wilhemus

\section{Lembaga Penelitian}

Sekolah Tinggi Keguruan dan IImu Pendidikan "Widya Yuwana" MADIUN 


\section{JPAK \\ JURNAL PENDIDIKAN AGAMA KATOLIK}

Jurnal Pendidikan Agama Katolik (JPAK) adalah media komunikasi ilmiah yang dimaksudkan untuk mewadahi hasil penelitian, hasil studi, atau kajian ilmiah yang berkaitan dengan Pendidikan Agama Katolik sebagai salah satu bentuk sumbangan STKIP Widya Yuwana Madiun bagi pengembangan Pendidikan Agama Katolik pada umumnya.

Penasihat

Ketua Yayasan Widya Yuwana Madiun

Pelindung

Ketua STKIP Widya Yuwana Madiun

Penyelenggara

Lembaga Penelitian STKIP Widya Yuwana Madiun

Ketua Penyunting

Hipolitus Kristoforus Kewuel

Penyunting Pelaksana

FX. Hardi Aswinarno

DB. Karnan Ardijanto

Penyunting Ahli

John Tondowidjojo

Ola Rongan Wilhelmus

Armada Riyanto

Sekretaris

Gabriel Sunyoto

\section{Alamat Redaksi}

STKIP Widya Yuwana

Jln. Mayjend Panjaitan. Tromolpos: 13. Telp. 0351-463208. Fax. 0351-483554 Madiun 63137 - Jawa Timur - Indonesia

Jurnal Pendidikan Agama Katolik (JPAK) diterbitkan oleh Lembaga Penelitian, STKIP Widya Yuwana Madiun. Terbit 2 kali setahun (April dan Oktober). 


\section{JPAK}

Vol. 9, Tahun ke-5, April 2013

ISSN; 2085-0743

\section{DAFTAR ISI}

2 Editorial

4 Pastoral Pengaturan Kehamilan Seturut Ajaran Moral Gereja Katolik

Antonius Virdei Eresto Gaudiawan, M.Hum.

29 Arah Dasar Pendidikan Kita

Prof. Dr. John Tondowidjojo, CM

42 Pendidikan Karakter dalam Pembelajaran Agama Katolik di SMASanto Bonaventura Madiun

Murlani

81 Pendidikan Kristiani Melalui Pengalaman Berkomunitas bagiAnak-anak

Albert I Ketut Deni W.

91 Mendidik Murid Menjadi Pendidik Iman

Agustinus Supriyadi

100 Komunitas Basis Gerejani

Ola Rongan Wilhemus 


\title{
PASTORAL PENGATURAN KEHAMILAN SETURUT AJARAN MORAL GEREJA KATOLIK
}

\author{
Antonius Virdei Eresto Gaudiawan, M.Hum.
}

\section{Sekolah Tinggi Keguruan dan Ilmu Pendidikan Agama Katolik (STKIP) Widya Yuwana Madiun}

\begin{abstract}
Magisterium of the Church has established sexual ethics for a long time ago. Church resists artificial birth control that morally are contraceptive and abortive. Church gives guidance for Christian to use natural birth control recognized as a gift of God. Nevertheless, many Christian have used artificial birth control. Some researches affirmed this judgment. Thereof, the Church has to continuously invite Christian couples for using natural birth control throughout their life. Church has to establish such a natural birth control centre for on going education both related to sexual ethics and the convince of the Christian couples effectively practicing natural birth control.
\end{abstract}

Keywords: sexual ethics, artificial birth control, natural birth control, contraceptive, abortive, research, natural birth control centre, on going education, affectivity and efficiency

\section{Pengantar}

Gereja sampai sejak awal sampai saat ini sangat menjaga moralitas dalam hal seksual dan prokreasi. Gereja memandang penggunaan alat-alat seksual dalam tubuh manusia sebagai sesuatu yang bermoral sejauh pertama-tama memiliki sifat prokreatif, yaitu terbuka dengan adanya keturunan. Itulah mengapa Gereja, dalam moral perkawinan dan moral seksual, dengan tegas melarang penggunaan metode-metode pengaturan kehamilan yang membuat hubungan seksual kehilangan jati dirinya yang prokreatif tersebut. 
Demikianlah dari kodratnya, semenjak diciptakan pria dan wanita, seksualitas adalah sesuatu yang berharga. Kepriaan dan kewanitaan diciptakan oleh Allah seturut gambaran diri Allah sendiri. Allah menciptakan pria dan wanita menurut rupa dan gambarNya. Pria dan wanita itu oleh Allah sendiri dipersatukan sehingga mereka menjadi suami dan istri. Mereka menjadi rekan sederajat. Mereka menjadi penolong yang sepadan. Perutusan suami dan istri itu adalah memenuhi bumi, dalam arti melanjutkan generasi berikutnya di bumi ini.

Sayangnya, di zaman global ini, dinamika sukses telah membuat manusia melupakan moralitas seksual yang telah diajarkan Gereja Katolik tersebut. Gereja berulangkali menyerukan ajaran tentang moralitas seksual dan pengaturan kehamilan. Tetapi apa lacur, tidak bisa dipungkiri bahwa banyak umat Katolik entah secara terang-terangan entah atau sembunyi-sembunyi tidak menjalankan ajaran dan anjuran Gereja Katolik ini.

Di sini muncul dua pertanyaan besar. Mengapa hal tersebut terjadi? Motivasi apa yang mendorong sehingga banyak umat katolik tidak mengindahkan ajaran Gereja ini. Tentu tidak cukup hanya bertanya mengapa, selanjutnya dipertanyakan bagaimana sebaiknya usaha-usaha pastoral yang bisa dibangun supaya keluarga-keluarga kristiani tetap menjalankan moralitas pengaturan kehamilan sebagaimana diajarkan oleh Gereja Katolik.

Untuk menjawab pertanyaan-pertanyaan tersebut, penelitian ini dilaksanakan dengan metode kualitatif induktif, hermenutik atau penafsiran. Penafsiran dibuat atas berbagai sumber-sumber tertulis yang ada baik di dalam buku maupun penelitian-penelitian sebelumnya.

\section{Pengaturan Kehamilan secara Umum}

Secara umum, metode pengaturan kehamilan itu ada dua jenis yaitu yang bersifat kontravita atau yang bersifat kontraseptif. Bersifat kontraseptif berarti bahwa metode pengaturan kehamilan itu mencegah terjadinya perjumpaan antara sel telur dan sel sperma. Artinya, jangan sampai terjadi pembuahan. Sementara metode kontravita merupakan metode pengaturan kelahiran yang dalam metodenya akan menyebabkan terjadinya keguguran atau penghentian kehamilan. Analisa ini tidak menitik beratkan pada soal buatan atau alamiah, tetapi lebih kepada upaya melihat dampak moral dari masing-masing metode pengaturan kehamilan. 


\subsection{Metode Pengaturan Kehamilan Kontraseptif}

Metode pengaturan kehamilan pada dasarnya adalah metode untuk menjarangkan terjadinya kehamilan. Metode penjarangan kehamilan yang bersifat kontraseptif yaitu menghalangi terjadinya peleburan antara sel telur dan sel sperma. Matode ini pada dasarnya terbagi menjadi dua bagian. Metode pertama adalah metode alamiah yang berarti tidak menggunakan bantuan alat atau hormon dari luar. Metode yang kedua adalah metode buatan yang berarti memanfaatkan berbagai sarana sehingga tidak terjadi pembuahan.

\subsubsection{Metode Pengaturan Kehamilan Kontraseptif Alamiah}

Pada dasarnya hanya ada satu metode pengaturan kehamilan kontraseptif alamiah yaitu coitus interuptus. Metode ini merupakan metode di mana suami istri melakukan hubungan seksual dan supaya tidak terjadi pembuahan, sperma dikeluarkan di luar liang sanggama dengan menghentikan penetrasi.

Metode ini cukup berbahaya. Ketika melakukan penetrasi, bisa saja sperma sudah keluar dahulu sebelum penetrasi dihentikan. Dari satu tetes air mani yang keluar sudah terkandung banyak sperma. Dengan demikian, tetap dimungkinkan terjadinya pembuahan.

Metode ini dalam pandangan Gereja Katolik dianggap tidak bermoral. Kasus ini bisa dilihat dalam Kejadian 38:9-10. Allah memandang tindakan Onan yang membuang mani keluar dari persetubuhannya dengan Tamar sebagai sesuatu yang jahat. Sedemikian jahat tindakan itu sehingga bahkan Allah sendiri menghukum Onan dengan menghentikan kehidupannya.

\subsubsection{Metode Pengaturan Kehamilan Kontraseptif Buatan}

Pada prinsipnya, metode pengaturan kehamilan dengan kontraseptif buatan adalah metode kehamilan dengan membuat barier atau penghalang. Penghalang buatan itu menyebabkan sel sperma dan sel telur tidak bertemu.

Ada empat jenis metode barier ini yaitu kondom, cervical cap, spermicide, dan diapragma (lih. Virdei Eresto G. 2011. Keluarga Berencana dan Praktik KB dalam Keluarga Katolik. hal. 157-160). Sebagai metode pengaturan kehamilan, metode ini lebih jarang dipilih oleh pasangan suami istri karena pelaksanaannya membutuhkan biaya lebih.

Akan tetapi, Majelis Waligereja Indonesia pernah mengeluarkan anjuran tentang pengaturan kehamilan tahun 1975 yang cenderung memperbolehkan metode ini karena dipandang memiliki 
tingkat kesalahan moral yang lebih rendah daripada memakai metode-metode pengaturan kehamilan hormonal yang cenderung bersifat kontraseptif. Dalam situasi terjepit, suami istri dapat memilih salah satu metode pengaturan kehamilan yang kadar kesalahan moralnya lebih kecil.

Berkaitan dengan anjuran pastoral tersebut, Gereja Katolik universal tetaplah memandang pemakaian metode pengaturan kehamilan yang bersifat kontraseptif apalagi yang bersifat kontravita adalah metode pengaturan kehamilan yang tidak bermoral. Karena tidak bermoral, tidak boleh dilakukan oleh umat beriman. Artinya, anjuran Majelis Waligereja Indonesia tahun 1975 itu ditolak oleh otoritas Gereja.

\subsubsection{Metode Pengaturan Kehamilan Kontraseptif Tetap}

Pengaturan kehamilan kontraseptif tetap berbeda dengan dua metode kontraseptif sebelumnya. Dua metode sebelumnya dibagi menjadi metode alami dan buatan. Metode kontraseptif tetap ini sebetulnya juga metode kontraseptif buatan. Yang berbeda adalah masanya. Metode kontraseptif buatan di atas cenderung bersifat sementara. Sementara metode kontraseptif tetap adalah metode kontraseptif buatan yang bersifat tetap dan tidak bisa dengan muda diperbaiki kembali.

Metode tetap yang dimaksudkan di sini adalah metode tubektomi dan vasektomi (lih. Virdei Eresto G. 2011. Keluarga Berencana dan Praktik KB dalam Keluarga Katolik. hal.167-168). Tubektomi dilakukan pada wanita dengan memotong atau mengikat tubafalopi sehingga sel telur setelah matang tidak bisa bergerak menuju rahim. Pemotongan atau pengikatan tubafalopi tersebut menyebabkan tidak terjadinya pertemuan antara sel telur dan sel sperma. Sementara metode vasektomi adalah metode yang dilakukan pada pria dengan memotong atau mengikat saluran vas deferens sehingga sperma tidak keluar. Ketika terjadi ejakulasi, seorang pria yang divasektomi hanya akan mengeluarkan semen atau cairan mani saja. Cairan itu tidak mengandung benih atau sperma. Akibatnya, ketika melakukan hubungan seksual tidak pernah ada sperma yang keluar dan membuahi sel telur wanita.

Metode ini juga ditentang oleh Gereja Katolik karena metode ini mengurbankan bagian tubuh manusia tanpa sesuatu yang memberi dampak yang baik pada keutuhan pribadi. Dalam kasus ini hendaklah dilihat kasus di mana ada seorang yang sakit gula pada kakinya 
hingga membusuk. Sakit itu tidak bisa disembuhkan. Jika dibiarkan begitu saja, maka busuknya kaki itu akan segera menyebar dan akhirnya mengganggu keutuhan diri orang karena terlalu berkonsentrasi pada kaki yang sakit itu. Demikianlah dalam kasus ini, memotong kaki yang busuk itu bermoral karena baik untuk menjaga keutuhan pribadi manusia. Ketika kaki tidak dipotong, maka keutuhan pribadi menjadi sulit. Dalam kasus vasektomi dan tubektomi, pemotongan atau pengikatan bagian tubuh manusia itu tidak berguna atau berdampak bagi keutuhan diri manusia itu. Tidak ada yang rusak dalam tubuh pria dan wanita yang akan divasektomi atau ditubektomi. Dalam hal ini, tidak ada satu pun keuntungan vasektomi dan tubektomi dalam rangka keutuhan pribadinya sebagai manusia. Vasektomi dan tubektomi melanggar prinsip pars prototo dalam diri manusia.

Metode pengaturan kehamilan melalui vasektomi dan tubektomi itu dilarang oleh Gereja Katolik karena tidak bermoral dalam arti memotong atau menghilangkan bagian dari tubuh manusia tanpa membawa dampak yang baik bagi keutuhan pribadi manusia. Salah satu bahaya dari vasektomi dan tubektomi adalah instrumentalisme pada fungsi organ-organ seksual manusia hanya sekedar demi mencapai kenikmatan hidup manusia tanpa mengindahkan tujuan kodrati dari organ-organ seksual tersebut.

\subsection{Metode Pengaturan Kehamilan Kontravita}

Merujuk pada keterangan terdahulu, metode pengaturan kehamilan kontravita pada dasarnya adalah metode pengaturan kehamilan yang dalam cara kerjanya menyebabkan terjadinya penghentian kehamilan. Metode ini terbagi menjadi dua yaitu metode yang menggunakan hormon serta metode yang menggunakan alat yang dimasukkan ke dalam organ reproduksi wanita.

\subsubsection{Metode Pengaturan Kehamilan Kontravita dengan Hormon \\ Beberapa metode pengaturan kehamilan dengan hormon antara} lain dengan pil kb, morning after pills, pil mini, depo provera, prostlagandin, implanon, contraceptive patch, vaginal contraceptive ring, dan extended cycles pills (Virdei Eresto G. 2011.Keluarga Berencana dan Praktik KB dalam Keluarga Katolik. hal. 160-165). Metode ini sering dijumpai dalam pelaksanaan program KB yang dianjurkan oleh pemerintah. 
Berbagai metode pengaturan kehamilan dengan hormon ini memiliki pola atau kemiripan yang sama. Pola pertama adalah memberikan rangsangan hormonal sehingga meningkatkan keasaman dalam serviks sehingga sperma akan mati ketika dalam perjalanan menuju ke dalam rahim. Pola kedua adalah membuat terhambatnya hormon progesteron yang berfungsi menyiapkan terjadinya nidasi di dalam rahim. Terhambatnya hormon progesteron menyebabkan persiapan untuk nidasi tidak segera terjadi atau melambat. Ini mengakibatkan embrio, hasil peleburan sel telur dan sel sperma, ketika seharusnya menempel pada dinding rahim, akhirnya tidak bisa menempel dengan sempurna. Hal ini menyebabkan terjadinya kematian pada embrio. Inilah yang disebut sebagai kontravita atau pembunuhan embrio yang sejak adanya, yaitu peleburan sel telur dan sel sperma, pada dasarnya adalah manusia yang bernilai sebagai persona.

Sebagai metode pengaturan kehamilan, metode ini sangat ditentang karena bersifat abortif. Derajat kesalahan moralnya jauh lebih besar daripada metode kontraseptif. Gereja meyakini ketika terjadi peleburan sel telur dan sel sperma, di sana sudah terdapat entitas manusia yang baru. Entitas manusia itu memang berbeda dengan kelengkapan seperti manusia yang sudah bisa hidup di luar rahim. Akan tetapi, embrio itu sendiri sudah memiliki kemampuan untuk menentukan dirinya sendiri. Oleh karena itu, meskipun masih berupa embrio satu sel, dia tetap berharga sebagai persona.

Dalam hal ini harus diingat berbagai macam konsep homonisasi (proses menjadi manusia) yang ada di dalam kelompok agama atau kepercayaan yang lain. Ada kelompok yang memandang bahwa jiwa manusia baru ada ketika terjadi quickening. Quickening yaitu saat di mana bayi di dalam rahim mulai menendang. Sebelum ada tendangan itu, bayi belum dianggap sebagai manusia karena belum memiliki jiwa manusia. Oleh karena itu, aborsi yang dilakukan sebelum bayi melakukan quickening adalah bermoral. Namun, praktis pandangan ini ditentang oleh Gereja Katolik.

\subsubsection{Metode Pengaturan Kehamilan Kontravita dengan Alat Tambahan}

Metode pengaturan kehamilan ini biasa disebut sebagai alat kontrasepsi dalam rahim (AKDR). Prinsip dasar metode ini adalah memasukkan alat ke dalam rahim yang berfungsi untuk mencegah terjadinya kehamilan. Alat-alat yang dipakai dalam metode ini antara 
lain copper T, Tcu-380A, Micu375, LNG20, Nova T, Mirena, Paragard IUD dan sebagainya (lih. Virdei Eresto G. 2011. Keluarga Berencana dan Praktik KB dalam Keluarga Katolik. hal. 165-167).

Metode pengaturan kehamilan dengan intra uterine device ini pada dasarnya memiliki satu pola umum dan satu pola tambahan. Satu pola umum adalah alat ini berfungsi untuk mengurangi potensi terjadinya nidasi atau penempelan embrio pada dinding rahim. Sementara itu, satu pola tambahannya adalah ada alat kontrasepsi dalam rahim yang juga mengeluarkan hormon progestin yang fungsinya menghambat kerja hormon progesteron yang diperlukan untuk menyiapkan terjadinya nidasi.

Sebagaimana sudah dijelaskan pada metode hormonal, karena alat ini bekerja dengan mencegah potensi terjadinya nidasi, maka alat ini termasuk alat yang bersifat abortif. Dalam penilaian moral, menjadi jelas bahwa alat ini memiliki tingkat kesalahan moral yang tinggi. Karena itu, jelas-jelas metode ini ditolak oleh Gereja Katolik.

\section{Pengaturan Kehamilan yang Bermoral menurut Gereja Katolik}

Kalau demikian apa saja metode pengaturan kehamilan yang dipandang bermoral oleh Gereja Katolik? Pada prinsipnya, Gereja Katolik hanya mengakui metode pengaturan alamiah sebagai metode yang bermoral. Prinsip dasar metode ini adalah tindakan seksual suami istri dilaksanakan secara manusiwi sedemikian rupa sehingga dari persetubuhan itu dimungkinkan terjadinya pertemuan sel telur dan sel sperma. Dimungkinkan artinya bisa jadi ada peleburan bisa jadi tidak ada peleburan. Prinsip dasarnya adalah open to life yang berarti keterbukaan akan adanya keturunan.

Prinsip dasar metode pengaturan kehamilan alamiah adalah metode pantang berkala. Artinya, suami istri diharapkan berpantang dari hubungan seksual ketika sedang dalam masa-masa subur atau masa-masa di mana kalau hubungan seksual dilakukan akan terjadi peleburan sel sperma dan sel telur. Untuk melaksanakan metode ini, tentu diharapkan komitmen dari suami istri. Justeru dengan metode alamiah ini dihargai keluhuran martabat seksualitas dan pasangan. Bahwa pasangan bukan sekedar sebagai pemuas nafsu belaka, tetapi menjadi partner atau penolong yang sepadan bagi dirinya.

Metode alamiah ini tidak bertentangan dengan pandangan Gereja Katolik karena metode ini memanfaatkan siklus alamiah yang memang sedemikian rupa diciptakan oleh Allah. Oleh karena itu, 
Gereja memandang bahwa persetubuhan yang dilakukan di masamasa di mana tidak mungkin terjadi pembuahan pada dasarnya adalah bermoral. Selanjutnya akan dijelaskan secara singkat masing-masing metode.

\subsection{Metode Kalender}

Dimaksud dengan metode kalender adalah metode pengaturan kehamilan dengan menghitung siklus menstruasi seorang wanita. Normalnya, siklus menstruasi seorang wanita adalah 28 hari (lih. Virdei Eresto G. 2011. Keluarga Berencana dan Praktik KB dalam Keluarga Katolik. hal. 168-169).

Dengan menghitung siklus menstruasi seorang wanita, bisa diketahui kapan masa subur dan kapan masa tidak subur. Dengan demikian menggunakan waktu-waktu tidak subur untuk melakukan hubungan seksual tidak akan menyebabkan terjadinya pembuahan.

Problem pokok yang berkaitan dengan metode ini adalah keteraturan siklus menstruasi seorang wanita. Tidak semua wanita memiliki siklus menstruasi yang stabil. Bahkan, seringkali faktor psikologis juga memengaruhi siklus seorang wanita sehingga bisa maju atau mundur. Metode ini boleh dikatakan memiliki tingkat kegagalan yang cukup tinggi.

Beberapa kasus dapat dilihat misalkan dalam situasi pasanganpasangan yang baru saja menikah. Sebelum menikah mereka membayangkan untuk baru hamil satu tahun atau enam bulan sesudah menikah. Mereka mencoba menerapkan metode alamiah dengan berprinsip bahwa melakukan hubungan seksual setelah menstruasi pastilah tidak akan menghasilkan pembuahan. Tetapi kenyataan yang sering terjadi, ketika menikah seorang wanita mengalami siklus yang berubah karena beban psikologisnya. Akibatnya, menstruasi maju dan setelah itu dimulailah masa persiapan untuk subur. Hubungan seksual di periode ini, jika hanya berdasarkan metode kalender bisa berpotensi terjadinya keturunan.

Pertanyaannya apakah kemudian metode ini tidak bermanfaat? Menurut hemat kami, metode ini tetap bermanfaat bagi keluargakeluarga kristiani. Menggunakan metode ini memang tidak bisa sendiri. Artinya, harus ditemani atau dibarengi dengan metodemetode pengaturan kehamilan yang lainnya.

Keuntungan metode ini ialah pengenalan siklus diri pribadi seorang wanita. Harus disadari bahwa tidak semua wanita, apalagi dalam budaya timur, mau dengan terbuka mengamati dan memahami siklus tubuhnya sendiri. Pengalaman menunjukkan betapa para ibu 
sering merasa malu dan resah ketika diterangkan soal siklus menstruasi dan organ reproduksi mereka.

\subsection{Metode Suhu Basal}

Metode suhu basal adalah metode pengaturan kehamilan dengan mengamati perubahan suhu dalam tubuh seorang wanita (lih. Virdei Eresto G. 2011. Keluarga Berencana dan Praktik KB dalam Keluarga Katolik. hal. 169-170). Suhu basal diukur segera setelah seorang wanita bangun dari tidur tetapi belum beranjak dari tempat tidur.

Ketika mengalami ovulasi, atau masa subur, suhu basal seorang wanita akan cenderung turun sebelum mengalami ovulasi dan cenderung naik setengah derajat ketika mengalami ovulasi. Perubahan atau kenaikan suhu ini bisa menjadi tanda adanya kesuburan dalam diri seorang wanita.

Metode ini cukup berisiko karena suhu tubuh seorang wanita juga bisa dipengaruhi oleh berbagai faktor seperti stress, pola minum, kesehatan, capek dan sebagainya. Metode ini sebaiknya menjadi pelengkap untuk semakin memahami siklus seorang wanita.

Dalam pandangan Gereja Katolik, metode ini dianggap bermoral. Di sini, tidak ada usaha untuk menghalangi terjadinya pembuahan, tetapi lebih karena memang pembuahan itu sendiri tidak akan terjadi dari kodratnya.

\subsection{LactationalAmenorrhea Method (LAM)}

Metode ini adalah metode menyusui bayi (lih. Virdei Eresto G. 2011. Keluarga Berencana dan Praktik KB dalam Keluarga Katolik. hal. 171-172). Seorang wanita yang sering menyusui bayinya akan memproduksi hormon prolaktin yang akan menekan hormon yang mengatur terjadinya ovulasi. Dalam hal ini hendaknya ibu menyusui kurang lebih 3-4 jam sehari.

Metode ini tidak bisa diterapkan jika wanita setelah melahirkan, dalam jangka beberapa waktu kemudian, mengalami menstruasi. Metode ini mendukung gerakan ASI eksklusif. Biasanya metode ini bisa berjalan dalam waktu satu tahun, tetapi sekarang ini mulai dikurangi menjadi hanya enam bulan semenjak seorang wanita melahirkan.

Dari segi efektivitas, metode ini cukup baik akan tetapi juga beresiko kalau hormon prolaktin yang dihasilkan ibu yang menyusui tidak cukup menekan produksi hormon FSH dan LH. Oleh karena itu, metode ini memiliki masa yaitu sebelum mengalami menstruasi. Setelah mengalami menstruasi, metode ini tidak bisa dipakai. 
Dalam pandangan Gereja Katolik, metode ini tidak bermasalah secara moral karena tidak menghalangi terjadinya peleburan sel telur dan sel sperma ketika suami istri melaksanakan hubungan seksual:

\subsection{Metode Ovulasi Billings}

Metode pengaturan kehamilan alamiah yang sampai saat ini paling banyak diajarkan adalah metode ovulasi billings (lih. Virdei Eresto G. 2011. Keluarga Berencana dan Praktik KB dalam Keluarga Katolik. hal. 170-171). Metode ini adalah metode yang sangat mudah untuk diterapkan dalam keluarga-keluarga katolik.

Prinsip dasar metode ini adalah memerhatikan siklus kesuburan seorang wanita dengan memerhatikan mucus atau lendir yang dihasilkan di dalam vagina seorang wanita. Kondisi mucus itulah yang menjadi penanda kesuburan atau ketidaksuburan.

Kalau lendir mengental dan agak licin itu berarti proses pematangan baru dimulai. Kalau mucus mulai mulur berarti pematangan sel telur makin memuncak. Dan ketika mucus itu bisa sangat mulur, berarti itulah puncak ovulasi. Begitu selanjutnya ketika setelah mengalami ovulasi lendir kemudian memendek, mengental dan kemudian hilang.

Untuk memahami metode ini dengan sangat gamblang, telah disediakan web dari doktor Billings untuk menjelaskan tentang metode ini dengan alamat http://www.billingsmethod.org/bom/ lit/teach/index_id.html. Ada berbagai bahasa dalam web tersebut. Bahkan penjelasan dalam bahasa Indonesia pun sudah ada.

Secara ringkas, berikut dikutip peraturan metode billings baik untuk mendapatkan keturunan maupun untuk menunda keturunan (diunduh dari http://www.billingsmethod.org/bom/lit/teach/ index_id.html).

\subsubsection{Peraturan Metode Billings}

(1)Untuk Mencapai Kehamilan:

Digunakan Peraturan Pra-Ovulasi. Cara ini membantu untuk mengenal perubahan pola kesuburan lendir. Kemudian, hubungan seksual harus ditunda sampai lendir licin tampak. Beberapa hari berikutnya adalah hari yang paling subur. Oleh karena itu, hubungan seksual hendaknya dilakukan selama ada lendir licin (vulva terasa licin).

(2)Untuk Menunda/Menjarangkan Kehamilan: 


\subsubsection{Peraturan Pra Ovulasi}

Peraturan 1 : Hindarilah hubungan seksual pada hari-hari pendarahan deras selama menstruasi.

Peraturan 2 : Hubungan seksual boleh dilakukan pada setiap malam hari kedua (selang-seling), bila hari ini sudah dikenal sebagai tidak subur.

Peraturan 3 : Hindarilah hubungan seksual setiap hari ketika lendir atau pendarahan menyelingi Pola Dasar Tidak Subur (PDTS). Hubungan seksual baru boleh dilakukan lagi bila 3 hari berturut-turut dikenali sebagai PDTS, maka hubungan seksual boleh dilakukan pada malam ke-4. Selanjutnya gunakanlah peraturan 2 .

Peraturan 4 : Mulai hari ke-4 sesudah Puncak sampai akhir siklus, boleh melakukan hubungan seksual setiap hari pada setiap saat.

Metode ini sebetulnya sangat sederhana namun demikian bisa dijumpai kenyataan bahwa metode ini tidak terlalu dipakai di Indonesia. Lebih banyak penyuluh KB di Indonesia yang mengajarkan penggunaan alat-alat $\mathrm{KB}$ daripada mengajarkan metode ovulasi billings ini.

Tingkat keberhasilan metode ini sangat tinggi. Tentu sebagai sebuah metode sejauh metode diterapkan dan ditaati dengan tepat. Seringkali ada pasangan suami istri yang tledor dalam menggunakan metode ini sehingga terjadilah kehamilan.

Gereja Katolik sangat mendukung metode ini karena tidak merusak moralitas seksual dan sekaligus juga efektif. Inilah mengapa penjelasan metode ini sangat dianjurkan dan dipakai dalam kursus persiapan perkawinan.

\section{Realitas Umat Beriman terkait Pengaturan Kehamilan}

Meskipun Gereja Katolik sejak dahulu kala mengajarkan moralitas seksual yang benar dan metode pengaturan kehamilan yang benar, harus disadari kenyataan bahwa di sana sini masih saja ada banyak umat katolik di sekitar kita yang tidak menggunakan metode pengaturan kehamilan sebagaimana yang telah diajarkan oleh Gereja Katolik.

Beberapa kenyataan sering dijumpai. Dalam sharing-sharing 
hidup perkawinan atau juga gojegan di antara pasangan-pasangan suami istri, sering terjadi cerita-cerita di mana pasangan-pasangan katolik menggunakan metode pengaturan kehamilan yang tidak dianjurkan oleh Gereja Katolik. Mereka menggunakan metode pengaturan kehamilan yang banyak dibuat atau dianjurkan oleh negara.

Beberapa peneliti pernah dengan metode masing-masing mengadakan penelitian tentang penggunaan metode pengaturan kehamilan alamiah di kalangan umat katolik. Beberapa bisa dikutip dan dimaknai dalam tulisan ini. Secara khusus, hasil penelitian ini diambil dari penelitian yang pernah dilakukan para mahasiswa STKIP Widya Yuwana Madiun ketika mereka mengerjakan tugas akhir. Oleh karena itu disini dicantumkan nama peneliti, tempat penelitian dan tahun penelitian.

Sugiyono pernah mengadakan penelitian tentang keluarga berencana bagi umat katolik di Stasi Kampungbaru Paroki Pare. Penelitian dilakukan pada tahun 2001. Penelitian dilakukan terhadap 40 responden. Dari penelitian itu, disimpulkan bahwa $80 \%$ umat beriman telah mengetahui adanya metode pengaturan kehamilan alamiah (KBA). Dari seluruh responden, ternyata yang memakai atau menerapkan metode pengaturan kehamilan alamiah dalam hidupnya hanya $60 \%$. Itu artinya hanya $75 \%$ umat yang mengetahui metode pengaturan kehamilan alamiah yang akhirnya melaksanakan metode pengaturan kehamilan tersebut. Dari penelitian tersebut, $40 \%$ responden menggunakan metode pengaturan kehamilan buatan baik yang kontraseptif dengan metode barier ataupun metode kontravita dengan hormonal.

Penelitian yang lain dibuat oleh Slamet Riyanto pada tahun 2007. Dia meneliti tentang penerapan keluarga berencana bagi umat katolik di stasi Santo Yakobus Sekarang Paroki Santo Matius Pare Benda. Penelitian dilakukan dengan meneliti 50 sampel pasangan suami istri dalam usia subur (Pasangan Usia Subur - PUS). Dari 50 sampel umat yang diteliti, ternyata $8 \%$ menggunakan metode pengaturan kehamilan alamiah, $8 \%$ menggunakan metod barier, sementara $18 \%$ menggunakan metode barier tetap, dan sisanya $66 \%$ menggunakan metode kontravita baik itu hormonal maupun alat kontrasepsi dalam rahim. Hal itu terjadi karena umat yang mengetahui tentang metode pengaturan kehamilan alamiah hanya $26 \%$ sementara $56 \%$ yang lain tidak mengetahui sama sekali metode pengaturan kehamilan alamiah sementara $18 \%$ sisanya tidak 
memberikan alasan yang jelas.

Penelitian selanjutnya adalah penelitian saudari Seilha Romana. Beliau meneliti tentang praktik keluarga berencana alamiah di paroki Santo Pius X Blora. Dari lima puluh respondan, 63\% responden mengikuti program keluarga berencana buatan sementara $36,7 \%$ tidak mengikuti program KB. Mereka yang mengikuti program Keluarga Berencana Alamiah (KBA) $28,3 \%$ sementara KBB adalah $71,7 \%$. Hal itu terjadi karena $80 \%$ responden memandang bahwa KBB (menggunakan metode pengaturan kehamilan buatan) adalah lebih efektif, sementara 20\% mengatakan bahwa KBB tidak efektif. Mereka yang memandang bahwa KBA lebih efektif hanya $28,3 \%$ dan sisanya $71,7 \%$ mengatakan bahwa KBA tidak efektif. Apa yang terjadi di paroki Santo Pius X Blora itu karena responden yang memiliki informasi lebih banyak tentang KBB daripada KBA adalah $66,7 \%$. Mereka yang memiliki informasi lebih banyak tentang KBA hanya $23,3 \%$.

Berkaitan dengan persepsi umat tentang praktik KBA, ditemukan bahwa $56,6 \%$ responden cenderung memilih menggunakan KBB sementara hanya $43,4 \%$ yang cenderung memilih menggunakan KBA. Itulah mengapa mereka pun mengatakan tidak biasa melakukan pantang berkala 63,3\%. Mereka yang biasa pantang berkala hanya $36,7 \%$.

Meskipun kecenderungan mayoritas adalah menggunakan metode pengaturan kehamilan buatan, mereka menyadari pandangan moral seksual Gereja bahwa setiap tindakan persetubuhan haruslah terbuka terhadap adanya keturunan. Hal itu dipahami oleh $88,4 \%$ responden. Berhadapan dengan pilihan moral mereka yang lebih memilih bertentangan dengan ajaran moral Gereja, 90\% responden merasa tidak menyesal.

Oleh karena responden juga menyadari kurangnya informasi tentang metode pengaturan kehamilan alamiah yang dianjurkan oleh Gereja, mereka mengusulkan supaya porsi materi mengenai KBA yang diberikan dalam kurus persiapan perkawinan perlu ditambah lagi. Hal ini didukung oleh $86,7 \%$ responden. Hal tersebut mereka sadari karena tidak semua paroki memiliki klinik KBA sehingga mereka sendiri tidak mudah untuk memperdalam pemahaman tentang KBA. Hal ini dinyatakan oleh $90 \%$ responden.

Apa yang bisa disimpulkan dalam problem ini dari berbagai penelitian tersebut? Rasanya tidak ada yang terlalu jauh berbeda antara apa yang telah diteliti oleh para peneliti dengan pengalaman 
yang penulis jumpa di lapangan. Memang harus disadari tidak sedikit umat beriman yang mengerti tentang ajaran moral seksual Gereja. Tetapi, mereka pada akhirnya tetap memilih menggunakan metode pengaturan kehamilan yang buatan.

Pola-pola dalam penelitian dengan jelas menunjukkan bahwa umat beriman cenderung lebih banyak memilih menggunakan metode pengaturan kehamilan buatan. Memang disampaikan beberapa alasan mengapa memakai metode pengaturan kehamilan buatan yaitu karena pendidikan yang kurang atau juga kurang mendapat pengetahuan yang baik tentang metode pengaturan kehamilan alamiah itu sendiri.

Harus juga disadari bahwa alasan pokok lain mereka untuk lebih menggunakan metode pengaturan kehamilan buatan adalah efektivitasnya. Mereka merasa menggunakan alat-alat pengatur kehamilan itu potensi kegagalannya sangat kecil dibandingkan kalau mereka menggunakan metode pengaturan kehamilan alamiah. Hal itu antara lain dipicu dari kenyataan bahwa mereka tidak sering melakukan pantang berkala. Mungkin dalam hal ini telah terjadi pergeseran pola perilaku hubungan seksual di antara suami istri. Banyak suami istri yang sekarang agaknya lebih melihat hubungan seksual sebagai rekreasi dan bukan pertama-tama sebagai prokreasi.

Hal yang penting yang selanjutnya harus direfleksikan di sini adalah kenyataan bahwa mereka sebagai bagian dari umat Katolik, meskipun menyadari ajaran moral seksual dalam Gereja Katolik, ketika melakukan sesuatu yang bertentangan dengan ajaran moral ini tetapi tidak muncul rasa penyesalan di dalam diri mereka. Janganjangan di dalam diri para umat beriman lebih dipentingkan tujuan atau capaian daripada cara itu sendiri. Bukankah tujuan pokok metode pengaturan kehamilan adalah menjarangkan kelahiran sehingga bisa mendidik anak dengan lebih baik lagi. Dan itu sesutu yang baik dan berguna bagi masa depan anak. Oleh karena itu, tidak menjadi masalah kalau pengurangan frekuensi kelahiran itu dibuat melalui metode buatan yang jelas sudah teruji efektivitasnya.

Hal ini makin dikuatkan dengan kenyataan bahwa umat beriman tidak merasakan mendapat panduan atau pendampingan yang cukup jelas dan kontinu tentang metode pengaturan kehamilan yang alamiah. Waktu yang diberikan dalam kursus persiapan perkawinan untuk berbicara masalah metode pengaturan kehamilan alamiah seringkali terbatas. Pun pula, tidak ada pusat pendampingan pengaturan kehamilan alamiah di paroki-paroki. 


\section{Masa Depan Ajaran Gereja berkaitan Metode Pengaturan Kehamilan Alamiah}

Pertanyaan selanjutnya tentang masa depan ajaran Gereja itu sendiri. Zaman berubah, pola pikir masyarakat berubah. Akankah Gereja kelak mengubah ajaran moral seksual dan pencegahan kehamilan yang telah dibuat? Mari sekarang hal ini dicermati dan direfleksikan demi mendapatkan pemahaman yang cukup untuk melangkah ke depan.

Di sini dipertanyakan apakah Gereja juga akan menemukan kembali tempatnya di tengah modernitas sebagaimana Gereja telah berubah dalam menatap alam pikir modern. Kalau dahulu Gereja mengutuk Galileo Galilei dan Kopernikus, di zaman berikutnya Gereja berubah dan menerima mereka. Akankah Gereja juga mengalami perubahan seperti perubahan yang dia buat terhadap ilmu modern?

\subsection{Memilih yang Efektif dan Efisien}

Melihat dari data yang telah diteliti, umat beriman lebih memercayakan pengaturan kehamilan mereka pada metode pengaturan kelahiran buatan berkaitan dengan soal efektifitas dan efisiensi. Metode pengaturan kehamilan buatan dinilai efektifkarena dijamin mendekati seratus persen berhasil. Tingkat resiko ketidakberhasilan sangatlah kecil.

Hal kedua adalah efisiensi. Metode pengaturan kehamilan buatan yang dipilih kebanyakan pasangan suami istri bukanlah metode pengaturan kehamilan barier yang dibuat setiap kali melakukan hubungan suami istri. Kebanyakan yang dipilih adalah metode-metode yang bisa bertahan lama. Beberapa yang dipilih antara lain susuk, IUD, vasektomi ataupun tubektomi. Metode ini dipilih karena aplikasinya hanya sekali untuk jangka waktu yang cukup panjang sehingga tidak merepotkan. Metode pil KB kurang diminati karena membutuhkan keteraturan yang tinggi.

Soal efektifitas dan efisiensi ini penting karena manusia yang hidup pada zaman global ini adalah manusia yang biasa hidup dengan mudah. Penguasaan teknologi menjadi hal yang mempermudah. Oleh karena itu, hal-hal yang sulit pasti akan ditinggalkan. Sebagai contoh, alih-alih menulis dengan tulisan tangan, mahasiswa sekarang lebih suka membuat laporan atau catatan dengan mengetiknya di komputer. Orang yang hidup di zaman global ingin sesuatu yang cepat, praktis, efektif, dan efisien.

Metode pengaturan kehamilan alamiah dinilai tidak praktis 
karena memerlukan ketelitian dan kecermatan setiap hari. Metode buatan sebaliknya tidak perlu kecermatan setiap hari. Belum lagi bicara soal tingkat keberhasilan. Metode buatan mengandalkan kemampuan alat sehingga manusia bisa bebas dari perhitunganperhitungan yang rumit. Sementara metode alamiah menuntut kecermatan dan pengendalian yang setia dan rapih. Ini cenderung menyulitkan dan merepotkan.

\subsection{TidakMenyesal kalau Berbeda denganAjaran Moral Gereja}

Penelitian yang dilakukan saudari Seilha pada salah satu bagiannya menunjukkan bahwa pasangan suami istri, meskipun memahami ajaran Gereja, tetapi tetap tidak merasa bersalah atau menyesal ketika mereka memakai metode pengaturan yang melanggar apa yang diajarkan oleh Gereja. Apa artinya hal ini?

Untuk membandingkan hal ini pastaslah dibandingkani penilaian moral ini dengan problem pembunuhan misalkan. Dalam soal pembunuhan, pasti orang akan merasa menyesal. Penyesalan itu biasanya juga karena soal aturan atau hukuman yang diterima. Permasalahannya berbeda dalam kasus penggunaan metode kehamilan alamiah ini. Gereira nembuat aturan tetapi atorare itu kurang dilembagakan dengan maksimal pun pula kurang ada penerapan hukuman yang sepantasnya bagi yang melanggar.

Tidak mengherankan umat beriman ketika melanggar ajaran moral Gereja ini tidak memiliki rasa sesal. Ajaran Gereja ini berbeda dengan aturan tidak membunuh yang begitu dilembagakan melalui sepuluh perintah Allah. Ajaran moral Gereja tentang metode pengaturan kehamilan menurut pengamatan dan pengalaman tidak pernah diajarkan dengan begitu masif. Paling-paling problem ini hanya diajarkan untuk para calon teolog atau katekis atau guru agama. Dan kepada umat beriman, ajaran ini hanya diajarkan sekali seumur hidup yaitu ketika pasangan suami istri mau menikah. Kalau begitu, pada sisi ini, haruslah dikritisi sikap Gereja sendiri yang memandang problem ini penting tetapi kurang memberikan sosialisasi yang menyeluruh, masif dan konkret.

Pada sisi yang lainnya harus dilihat diri umat beriman sendiri. Kalau dalam Lumen Gentium ditegaskan bahwa umat beriman hendaknya membangun sikap taat terhadap magisterium jika berbicara perkara iman dan moral, di sini umat beriman memilih sikap yang tidak taat kepada ajaran magisterium itu. Dalam arti itu, umat beriman agaknya memandang ajaran moral tentang seksualitas ini sebagai hal yang tidak terlalu penting sehingga dilanggar bukanlah 
sebuah kesalahan yang perlu disesali.

\subsection{Sulit Membuat Pantang Berkala}

Prinsip dasar pantang berkala seringkali sulit dialami oleh keluarga-keluarga kristiani. Kebanyakan pasangan suami istri kurang mampu melaksanakan pantang berkala.

Dalam metode pengaturan kehamilan alamiah yang diakui oleh Gereja Katolik, prinsip dasar yang ingin dicapai adalah pantang berkala. Semua metode yang ada hanyalah alat bantu untuk mengetahui siklus kesuburan seorang wanita. Kunci pokok tetaplah pada diri suami istri sendiri untuk memutuskan tidak melakukan hubungan seksual di masa-masa subur seorang wanita.

Salah satu problem yang cukup penting dalam hal ini seringkali diungkapkan oleh para istri. Dalam siklus seorang wanita, ada masa kering, subur dan menstruasi. Problem yang seringkali terjadi adalah, ketika sedang kering seorang wanita cenderung kurang tertarik atau lebih sulit untuk melakukan hubungan seksual. Justru pada saat subur, seorang wanita memiliki ketertarikan untuk melakukan hubungan seksual yang tinggi. Padahal, prinsip pantang berkala melarang hubungan seksual pada masa-masa subur. Bagi seorang pria ini tidak ada masalah karena pria tidak mengenal siklus subur, kering dan sebagainya. Bagi seorang istri, hal ini bermasalah berkaitan dengan pola kesuburannya.

Sampai saat ini, problem ini belum mendapatkan solusi yang sepantasnya. Pertanyaannya apakah di sini juga tidak penting untuk menghargai siklus psikologis seorang wanita yang juga terkait dengan siklus hormonalnya tersebut? Jangan-jangan di dalam pantang berkala itu melulu kaum wanita yang harus berkorban lebih banyak daripada kaum pria.

Memang pantang berkala pada dasarnya adalah bentuk matiraga. Matiraga inilah yang makin sulit dibuat oleh orang di zaman global ini. Kebiasaan orang di zaman ini adalah membangun atau memiliki hidup yang mudah. Mudah berarti menggunakan berbagai kemampuan teknologi untuk membantu hidupnya. Hal ini berlawanan dengan prinsip dasar matiraga yaitu memilih cara yang lebih sulit daripada yang mudah. Inilah yang juga disebut sebagai kerendahan hati.

\subsection{Perubahan Cara Memandang Seksualitas}

Dewasa ini, seksualitas dipandang sebagai dewa yang harus 
dipuja dan ditonjolkan. Hal ini dengan gamblang bisa dilihat dari kenyataan-kenyataan yang ada di sekitar kita. Beberapa pantas disebut dan direfleksikan.

Telah terjadi perkembangan klinik atau terapi seksualitas baik langsung maupun tidak langsung. Yang dimaksudkan di sini antara lain adanya klinik konsultasi seksualitas entah di internet ataupun di majalah-majalah khusus wanita atau pria. Juga berkembang klinik atau terapi untuk membantu suami istri lebih memiliki kemampuan dalam melakukan hubungan seksual. Prinsip dasar yang berkembang di dalam hal-hal ini adalah seksualitas itu penting, mengasyikkan, menyehatkan sehingga perlu didayagunakan dengan baik. Jangan sampai terjadi disfungsi dalam alat-alat seksual karena itu bisa berbahaya bagi hidup suami istri.

Telah terjadi pergeseran makna kecantikan atau keindahan pada hal-hal yang bertendensi kepada hal-hal seksual. Hal ini biasanya terjadi pada kaum wanita. Hal ini antara lain bisa terlihat dalam mode berpakaian para wanita zaman ini. Kalau wanita pada periode sebelumnya lebih menekankan aspek kesopanan dan keanggunan, mode berpakaian sekarang ini lebih mau menunjukkan keindakan tubuh seseorang. Maka, kebanyakian pakaian sekarang ini bermodel "press body" atau "ketat". Jarang ada pakaian yang tidak ketat sekarang ini. Ataupun juga model berpakaian yang memungkinkan lawan bicara, atau temannya merasa tertarik secara seksual. Di balik apa yang terjadi ini, terdapat sebuah prinsip bahwa tubuh manusia diciptakan dengan indah oleh karena itu pankas untuk dilihat dan dinikmati.

Dunia industri perfilman juga menyebabkan pergeseran terhadap makna seksualitas. Hampir semua film dari "luar" pasti memiliki adegan ciuman atau hubungan seksual, entah langsung atau tidak langsung, entah penuh atau sebagian kecil saja. Teknik itu dipakai untuk meningkatkan ketertarikan penonton sehingga penonton tidak bosan menonton film. Pola-pola dalam film tersebut kemudian dipakai menjadi pola bagi orang-orang muda sekarang ini. Di sini ditekankan bahwa seksualitas itu sesuatu yang baik, biasa, dan tidak tabu untuk dibuka ke publik.

Mengaca dari situasi yang ada terlihat bahwa sekarang ini seksualitas dipandang sebagai sesuatu yang penting, mengasyikkan, menyehatkan, indah, baik, biasa, dan bukan sesuatu yang tabu. Cara pandang semacam ini tidak salah, tetapi kurang tepat. Ada satu dimensi yang dihilangkan dari semua pandangan itu yakni fungsi utama seksualitas yaitu prokreasi. Demikianlah telah terjadi 
pergeseran dari tujuan penciptaan terhadap seksualitas dengan apa yang terjadi saat ini.

Pemisahan paradigma seksualitas dari tujuan naturalnya yaitu prokreasi menyebabkan manusia memandang seksualitas itu menjadi tujuan dari dirinya sendiri. Tujuan hubangan seksual kemudian hanya sampai pada hubungan seksual itu sendiri. Tidak ada dimensi transendensi dari seksualitas itu sendiri. Transendensi dalam arti seksualitas ditempatkan dalam rangka keilahian atau kerjasama ilahi. Maka tidak heran muncul pandangan bahwa telah terjadi perubahan dari seksualitas sebagai prokreasi menuju rekreasi.

\subsection{Gereja tegas Berbicara tetapi kurangAksi}

Dari tiga penelitian yang ditampilkan di atas, ada kecenderungan umum responden yang mengatakan bahwa mereka tidak begitu mengetahui metode pengaturan kehamilan alamiah. Juga dikatakan bahwa seringkali tidak ada penjelasan yang memadai dalam kursus persiapan perkawinan. Tidak ada klinik KBA di parokiparoki sebagai tempat untuk konsultasi tentang KBA itu sendiri. Bahkan dalam level keuskupan sendiri, agaknya juga belum berkembang pusat kajian atau layanan KBA sebagai ujung tombak bagi Gereja Katolik sendiri.

Jika melihat sejarah pandangan moral seksual dalam Gereja Katolik, jelas bahwa pandangan tentang problem-problem ini sangat tegas dan jelas. Pandang-pandangan itu pun sudah sangat lama. Hanya sayangnya, dalam pengalaman di Indonesia ini, ajaran itu hanya sampai penegasan bahwa Gereja melarang metode pengaturan kehamilan buatan baik yang kontraseptif maupun yang kontravita. Gereja sangat kurang dalam menjelaskan dan memberikan bantuan lebih untuk mengenalkan metode pengaturan kehamilan yang sesuai dengan pandangan Gereja.

Tidak mengherankan kalau umat beriman mengetahui bahwa Gereja melarang umat beriman menggunakan metode pengaturan kehamilan buatan dan hanya mengijinkan memakai metode pengaturan kehamilan alamiah. Tetapi, mereka tidak pernah melaksanakannya karena tidak mengetahui metodenya atau caranya dengan jelas dan gamblang.

Mungkin juga ada kepercayaan Gereja kepada ahli-ahli medis katolik untuk menggalakkan dan menerangkan metode pengaturan kehamilan alamiah itu. Tetapi, para tenaga medis itu pun telah mendapatkan tugas dari negara untuk menggalakkan program 
KB dan itu berarti menggunakan metode pengaturan kehamilan buatan.

\subsection{Pemerintah Menggalakkan Metode Pengaturan Kehamilan Buatan}

Pemerintah Indonesia sejak dahulu sampai sekarang ini terus menggalakkan program KB. Hal itu antara lain dapat terlihat dengan jelas dalam berbagai poster atau spanduk yang terpasang entah di pinggir jalan ataupun di tempat-tempat umum seperti rumah sakit, puskesmas, terminal bus dan sebagainya. Tidak hanya itu, di lingkup warga, secara khusus RT, juga terdapat kader-kader K.B yang bertugas memberikan penyuluhan kepada warga masyarakat untuk ikut program keluarga berencana di mana di dalamnya dijelaskan soal metode pengaturan kehamilan. Dan pastilah yang akan diajarkan metode pengaturan kehamilan yang praktis yaitu $\mathrm{KBB}$.

Para bidan sendiri, entah mereka itu beragama katolik atau bukan, juga selalu menawarkan program KB kepada para ibu yang datang ke kliniknya entah untuk memeriksakan kehamilan atau memeriksakan balita mereka. Para bidan selalu mengajak para ibu untuk menjadi aseptor KB. Terutu yang mereka tawarkan adaiah program-program KB yang dianjurkan atau digalakkan oleh pemerintah. Itu berarti mereka menawarkan program KBB.

Untuk mendukung program tersebut, pemerintah memiliki badan yang disebut BKKBN (Badan Kependudukan dan Keluarga Berencana Nasional). Lembaga ini memiliki beberapa fungsi yaitu:

a. Perumusan kebijakan nasional di bidang pengendalian penduduk dan penyelenggaraan keluarga berencana;

b. Penetapan norma, standar, prosedur, dan kriteria di bidang pengendalian penduduk dan penyelenggaraan keluarga berencana;

c. Pelaksanaan advokasi dan koordinasi di bidang pengendaliaan penduduk dan penyelenggaraan keluarga berencana;

d. Penyelenggaraan komunikasi, informasi, dan edukasi di bidang pengendalian penduduk dan penyelenggaraan keluarga berencana;

e. Penyelenggaraan pemantauan dan evaluasi di bidang pengendalian penduduk dan penyelenggaraan keluarga berencana;

f. Pembinaan, pembimbingan, dan fasilitasi di bidang pengendalian penduduk dan penyelenggaraan keluarga berencana;

g. Penyelenggaraan pelatihan, penelitian, dan pengembangan 
dibidang pengendalian penduduk dan penyelenggaraan keluarga berencana (diunduh dari http://www.bkkbn.go.id/ ViewProfil. aspx?ProfilID=4).

Melihat apa yang telah dibuat pemerintah, tidak mengherankan bahwa program KBB ini menjadi sangat masif.

Mengaca pada realitas yang terjadi di tengah pasutri katolik dan juga di tengah negara ini, terlihat adanya tantangan-tantangan baik eksternal maupun internal yang mengancam usaha Gereja untuk mengembangkan pola pikir pantang berkala. Selanjutnya, dipertanyakan bagaimana sebaiknya usaha Gereja supaya ajaran yang agung itu tidak sekedar menjadi penghias dogma-dogma Gereja, tetapi menjadi hidup di tengah zmat beriman sendiri.

\section{Merumuskan Pastoral Pengaturan Kehamilan}

Tentu fokus dalam usaha pastoral ini adalah bagaimana umat beriman, terutama pasangan suami istri, dapat lebih yakin dan akhirnya memilih menggunakan metode pengaturan kehamilan alamiah. Dengan begitu, maka mereka telah mengikuti apa yang selama ini diajarkan oleh Gereja Katolik. Dalam hal itu, beberapa langkah penting untuk dilakukan.

\subsection{Mendirikan Pusat Kajian dan Layanan Penyuluhan KBA}

Pemerintah Indonesia tampaknya berhasil menggalakkan program $\mathrm{KB}$ dalam keluarga-keluarga. Hal itu karena mereka memiliki badan tersendiri yang mengurus masalah ini dan melaksanakan penyuluhan yang masif sampai di level bawah.

Meniru apa yang telah juga dibuat oleh pemerintah, Gereja Katolik umumnya, dan Gereja Katolik Indonesia pada khususnya, perlu mendirikan pusat layanan atau kajian KBA. Lembaga itu paling tidak harus didirikan di keuskupan atau kevikepan. Tugasnya adalah memikirkan strategi dan rencana penggalakan program KBA di tengah umat beriman.

Apakah badan atau lembaga ini mendesak? Menurut hemat kami lembaga ini mendesak karena ajaran moral Gereja yang luhur itu telah banyak tidak diikuti oleh umat beriman. Kalau Gereja memandang moral seksualitas ini sebagai sesuatu hal yang penting, maka kekeliruan yang selama ini terjadi di kalangan umat beriman haruslah segera dibenarkan. Akan tetapi, jika Gereja sendiri tidak begitu memandangnya sebagai penting, biarlah apa yang terjadi seperti sekarang ini. 


\subsection{Konsientisasi Terus Menerus akan Makna Seksualitas}

Kalau Gereja memandang moral seksual ini sebagai sesuatu yang penting, maka tidak ada cara yang lain kecuali Gereja terus menerus memberikan pengajaran ataupun katekese tentang moral seksual dan moral pengaturan kehamilan ini. Kapan pun dan dimanapun. Artinya, sejak masih muda sampai sudah berkeluarga. Semua lapisan umat beriman perlu mendapatkan penyadaran terus menerus.

Salah satu faktor mengapa umat beriman tidak memilih metode pengaturan kehamilan alamiah karena mereka tidak tahu. Bahkan ada juga umat beriman yang tidak memahami bahwa Gereja menolak KBB dan menganjurkan KBA. Dengan demikian, ini menjadi kesalahan dari pihak Gereja sendiri. Siapa yang bertanggung jawab? Dalam hal ini para gembala jiwa berserta dengan kaum awam yang memiliki kemampuan di bidang ini bertanggung jawab untuk mengadakan konsientisasi terus menerus.

Konsientisasi tidak hanya melulu soal apa dan bagaimana metode pengaturan kehamilan alamiah. Konsientisasi juga harus sampai sikap iman yang harus dibangun berkaitan dengan keluhuran seksualitas dan kerjasamanya dalam penciptaan.

Hendaknya dibangun sikap tobat dan sesal yang sepantasnya sehingga pasangan suami istri yang semula telah menggunakan metode pengaturan kehamilan yang buatan, baik itu yang kontraseptif maupun kontravita, mau berbalik dan menggunakan metode pantang berkala sebagaimana dianjurkan oleh magisterium.

\subsection{Menjelaskan bahwa KBA itu Efektif dan Efisien}

Salah satu keengganan pasangan suami istri dalam menggunakan metode pengaturan kehamilan alamiah adalah efektifitas dan efisiensinya. Banyak umat masih meragukan keefektifan metode KBA: Mereka masih memandang KBB lebih efektif. Hal ini terjadi karena banyak pasangan suami istri belum mendapatkan pengetahuan dan praktik yang cukup tentang metode pengaturan kehamilan alamiah. Padahal; metode ovulasi billings memiliki tingkat efektifitas yang tinggi juga.

Kepercayaan umat beriman terhadap metode ini harus dibuka kembali. Penjelasan yang cukup meyakinkan dan tidak ditutup-tutupi menjadi hal yang penting. Namun demikian, juga dibutuhkan sebuah pendampingan kontinu atau lanjutan sehingga pasangan suami istri dapat mengevaluasi, menguji atau membetulkan pemahamannya. 
Hal ini penting karena tidak setiap orang, ketika dijelaskan tentang metode KBA, langsung bisa menjalankannya dengan pasti dan benar. Ada orang-orang tertentu yang memang bisa segera melaksanakannya dengan baik dan benar karena memiliki pemahaman yang cukup, tetapi ada juga orang-orang yang memang harus dijelaskan berulang-ulang sehingga menjadi jelas baginya.

\subsection{Akankah ada sebuah Konsili Vatikan III?}

Para teolog moral pun sampai saat ini masih juga memperdebatkan soal metode pengatuan kehamilan alamiah ini. Yang diperdebatkan bukan soal efektivitasnya tetapi kenyataan yang dijumpai di lapangan yakni keluhan para ibu karena justru ketika mereka mengalami masa subur di mana mereka memiliki gairah yang tinggi, tetapi tidak boleh disalurkan karena harus berpantang. Bagi kelompok feminis, hal semacam ini bisa menjadi alasan bagi mereka untuk menyebutnya sebagai kekangan atau perendahan terhadap hak dan kebebasan kaum wanita. Sementara kaum pria sendiri tidak memiliki problem serius berkaitan dengan siklus ini.

Kalau magisterium sendiri dengan tegas menjelaskan bahwa tidak bersalah kalau dalam melakukan hubungan seksual itu suami istri mendapatkan kebahagiaan atau kenikmatan, pertanyaannya kapankah diberikan kesempatan kepada istri untuk boleh merasakan hal itu kalau harus berpantang ketika sedang masa subur? Bukankah hal juga berarti seorang wanita diperbolehkan mengalami pengalaman itu di masa subur mereka? Bagaimana memecahkan permasalahan ini. Ini merupakan sebuah permenungan panjang tentang moralitas dan hak.

Pertanyaannya, akankah ada sebuah Konsili Vatikan III yang bisa dengan tepat dan bijak menjawab problem ini dengan gamblang. Kalau dahulu Gereja menolak perkembangan ilmu modern yang dimotori oleh Galileo ataupun Kopernikus dan akhirnya sekarang ini menerimanya dengan tangan terbuka, berkenaan dengan problem yang masih tersisa, mungkinkah di suatu masa nanti Gereja akhirnya juga menerima metode pengaturan kehamilan buatan yang bersifat kontraseptif? Mungkin masih diharapkan sebuah Konsili Vatikan III untuk berbicara tentang masalah ini.

\section{Penutup}

Menyadari ajaran moral seksual yang diajarkan oleh Gereja telah membawa Gereja pada keyakinan moralnya untuk menolak 
metode pengaturan kehamilan buatan baik yang bersifat kontraseptif maupun kontravita. Gereja dengan teguh mengajarkan tentang metode pengaturan kehamilan alamiah sebagai sesuatu yang bermoral.

Penelitian dan berbagai kisah yang ada di kalangan suami istri katolik menunjukkan kenyataan bahwa ada tidak sedikit pasangan suami istri yang memilih tidak menggunakan metode pengaturan kehamilan alamiah sebagaimana telah diajarkan oleh magisterium sebagai sesuatu yang harus ditaati. Ada berbagai faktor yang melatarbelakangi mulai dari ketidaktahuan, keraguan akan efektivitasnya, perubahan pandangan akan seksualitas, serta gencarnya penawaran program KB oleh pemerintah Indonesia. Pun pula muncul pertanyaan tentang penghargaan atas siklus kesuburan seorang wanita sendiri.

Mengaca dari permasalahan itu, pantaslah untuk dikembangkan oleh Gereja yaitu lembaga kajian dan penyuluhan metode pengaturan kehamilan alamiah, konsientisasi terus menerus tentang ajaran moral Gereja, serta penegasan efektifitas metode pengaturan kehamilan alamiah. Pun demikian, masih tersisa masalah di antara para teologi sendiri ketika sampai di lapangan. Banyak istri dan ibu merasa keberatan dengan metode pengaturan kehamilan alamiah karena itu membuat mereka merasa dibatasi sebagai seorang wanita. Akankah ada perubahan ke depan? Inilah pertanyaan yang mungkin masih perlu dibawa dan direfleksikan secara mendalam.

\section{DAFTAR PUSTAKA}

Evelyn and Billings. http://www.billingsmethod.Org/bom/lit/teach/ index_id.html. Diunduh 12 Desember 2012.

Kusmaryanto, CB. 2006. Moral Hidup, Yogyakarta: FTW, Pro manuscripto.

MAWI. 1975. Anjuran Pastoral MAWI tentang Keluarga Berencana. Jakarta: MAWI.

Neuner, J., and J. Dupuis.2001. The Christian Faith in the Doctrinal Documents of the Catholic Church. New York: Alba House.

Purwa Hadiwardoyo.2004. Perkawinan dalam Tradisi Katolik. Yogyakarta: Kanisius. 
Seilha Romana, F. 2013. Praktik Keluarga Berencana Alamiah di Paroki Santo Pius X Blora. Madiun: STKIP Widya Yuwana, pro manuscripto.

Slamet Riyanto. 2007. Penilaian Moral tentang Penerapan Keluarga Berencana bagi Umat Katolik di Stasi Santo Yakobus Sekaran Paroki Santo Matius Pare Benda. Madiun: STKIP Widya Yuwana, pro manuscripto.

Sugiyono, F.X. 2002. Penilaian Moral tentang Keluarga Berencana. bagi Umat Katolik di Stasi Kampungbaru Paroki Pare Berdasarkan Pandangan Gereja Katolik. Madiun: STKIP Widya Yuwana, pro manuscripto.

Virdei Eresto G., Antonius. 2011. "Keluarga Berencana dan Praktik KB dalam Keluarga Katolik" dalam Jurnal Pendidikan Agama Katolik vol. 5 Tahunke-3, April 2011. Madiun: Wina Press.

Yohanes Paulus II, Apostolic Exhortation Familiaris Consortio, http://www.vatican.va/holy_father/john_paul_ii/apost. exhortations/documents/hf jp-ii exh 19811122 familiarisconsortio_en.html, diunduhtanggäl 12 September 2008. 